Relations industrielles

Industrial Relations

\title{
Our Third Annual Convention
}

\section{The Editors}

Volume 3, numéro 6, février 1948

URI : https://id.erudit.org/iderudit/1023602ar

DOI : https://doi.org/10.7202/1023602ar

Aller au sommaire du numéro

Éditeur(s)

Département des relations industrielles de l'Université Laval

ISSN

0034-379X (imprimé)

1703-8138 (numérique)

Découvrir la revue

Citer ce document

The Editors (1948). Our Third Annual Convention. Relations industrielles /

Industrial Relations, 3(6), 96-96. https://doi.org/10.7202/1023602ar

Tous droits réservés (C Département des relations industrielles de l’Université Laval, 1948
Ce document est protégé par la loi sur le droit d'auteur. L'utilisation des services d'Érudit (y compris la reproduction) est assujettie à sa politique d'utilisation que vous pouvez consulter en ligne.

https://apropos.erudit.org/fr/usagers/politique-dutilisation/ 


\section{OUR THIRD ANNUAL CONVENTION}

The third annual Convention of the Industrial Relations Department will take place on the 19th and 20th of April next. As in the past, our annual convention will be held at the Château Frontenac, where distinction and gracious hospitality always go hand in hand. The coming convention will turn out a success because of the co-operation of all those who have already taken part in our two previous ones. It will also be a success because it meets a social need. It will give economists, sociologists, lea ders in the fields of management and labour, personnel directors, labour officers and civil servants in the labour field an opportunity to express their views, stydy the problems with which they have to deal and renew useful connections.

The Industrial Relations Convention of Laval University is for employers and employees like a complement and extension of the annual congresses of their respective organizations. The essentially practical nature of union congresses does not allow the latter to use the lecture formula, which can be so appropriately applied to university congresses. Let us be thankful that men of action find time to devote themselves to study. The leaders of the people will therefore have greater wisdom.

The general subject to be studied during the course of the convention is entitled : «Forms of employer-employee co-operation». Such a title may seem a bit pretentious because of its vastness and comprehensiveness. However, we shall only deal with certain forms of co-operation; only such forms as we believe to be the most needed and the most likely to better the present condition of men.

Therefore, we shall study such co-operation both in the undertaking and in industry; 1-with respect to collective-bargaining (lecturer: Mr. Philippe Lessard, President of the National Federation of Pulp and Paper Workers Inc.); 2 - as regards labour-management committees (lecturer : Mr. Raymond Gérin, Secretary of the Quebec District Branch of the «Association professionnelle des Industriels》); 3 - as concerns vocational training (lecturer : Mr. Gabriel Rousseau, technical adviser on apprenticeship, Provincial Department of Labour); and 4 - with respect to Industrial Security, Medicine and Hygiene (lecturer: Dr Wilfrid LeBlond, professor of industrial hygiene at the Faculty of Social Sciences).

Each conference and subsequent discussion pertaining thereto shall take up a complete session. We have deemed it advisable not to overcrowd our programme so as to afford those attending the congress the opportunity of exchanging their views.

Though employer-employee co-operation is far from being a new idea, it is nevertheless full of present interest. Such a subject as the collective agreement seems a little out of date, but if it is analysed in relations to certain oppositions existing between the Labour Relations Act and the Collective Agreement Act, it becomes fascinating. Labour-management committees, also often referred to as works committees or joint production committees, enjoyed a certain amount of popularity during the course of the war when maximum production was a vital necessity. Why should such committees, which proved highly effective in wartime, be put aside in peacetime? Do we not have at hand the longed for opportunity to develop the form of co-operation for which we have all hoped without ever being to achieve it ? Highly successful initiatives have been brought about by the enactment of the Apprenticeship Assistance Act; they fully deserve to be known, and Capital, Labour and the State should jointly prepare new formulas of co-operation in that field. Finally, man's health must be protected; it is his most precious asset. Indeed, in the field of Industrial Security, Medicine and Hygiene we have many gaps to fill in, many ameliorations to bring about and many more innovations to make.

The Honourable Antonio Barrette, Minister of Labour, will preside over the banquet that will bring our convention to a close. The Right Reverend Father G.-H. Lévesque, o.p., Dean of the Faculty of Social Sciences of Laval University, has kindly accepted our pressing invitation for him to be the guest-speaker. The subject of his address ? . . . well, to find out, you will have to attend the banquet on Tuesday evening, April 20!

Our readers would be well advised not to delay in registering for the convention. Indeed, last year the number of registrations exceeded three hundred, and a greater number is expected this year ! Therefore, kindly avoid any delay, and you will thereby considerably ease the task of the organizers of our convention. Besides, are not the latter fully entitled to the prompt co-operation which the theme of the Convention inspires so eloquently? 